\title{
Terhességhez kapcsolódó szemészeti változások és a szülésvezetés módjának szemészeti kérdései
}

\author{
Czakó Cecilia dr. ${ }^{1}$ - Kovács Illés dr. ${ }^{1,2,3}$ - Sándor Gábor László dr. ${ }^{1}$ \\ Ecsedy Mónika dr. ${ }^{1}$ - Szabó Dorottya dr. ${ }^{1}$. Szécsi Dávid dr. ${ }^{4}$ \\ Benkovics Júlia dr. ${ }^{5}$ - Nagy Zoltán Zsolt dr. ${ }^{1}$ \\ 'Semmelweis Egyetem, Általános Orvostudományi Kar, Szemészeti Klinika, Budapest \\ ${ }^{2}$ Semmelweis Egyetem, Egészségtudományi Kar, Budapest, \\ ${ }^{3}$ Weill Cornell Medical College, Department of Ophthalmology, New York City, USA \\ ${ }^{4}$ Észak-Közép-budai Centrum, Új Szent János Kórház és Szakrendelő, Szülészeti és Nőgyógyászati Osztály, \\ Budapest \\ ${ }^{5} J a h n$ Ferenc Dél-pesti Kórház és Rendelőintézet, Szülészeti és Nőgyógyászati Osztály, Budapest
}

\begin{abstract}
A terhesség során a szervezet hormonrendszerében jelentős változások mennek végbe, melyek a magzat optimális anatómiai és élettani fejlődését, valamint a várandósság terminusig történő kihordását biztosítják. Ezen hatások sokszor a reproduktív szervrendszeren kívül más szerveket is érinthetnek, így a szemet és a szem függelékeit. A szemészeti változások élettani és kóros eltérésekben nyilvánulhatnak meg, melyek a legtöbbször átmenetiek és ártalmatlanok, bizonyos esetben azonban terápiás beavatkozást igényelhetnek, vagy súlyos háttérbetegség kórjelzői lehetnek. Közleményünkben áttekintjük a terhességhez kapcsolódó leggyakoribb fiziológiás szemészeti változásokat és egyéb patológiás szemészeti kórképeket, melyek a várandósság alatti megváltozott hormonális, immunológiai és metabolikus hatásokra kialakulhatnak, progrediálhatnak vagy fellángolhatnak. Ezenkívül ismertetjük a szülésvezetés módjának szemészeti indikációból történő eldöntésének vonatkozásait és a szülés kapcsán előforduló szemészeti szövődményeket.
\end{abstract}

Orv Hetil. 2021; 162(52): 2089-2099.

Kulcsszavak: terhesség, szemszárazság, miopizálódás, praeeclampsiához társult retinopathia, diabeteses retinopathia, császármetszés

\section{Pregnancy-related ocular changes and the choice of delivery mode in the presence of ophthalmological diseases}

During pregnancy, significant changes occur in the endocrine system that ensure the appropriate anatomical and physiological development of the foetus as well as smooth delivery at term. Apart from the reproductive system, these effects can affect other organs such as the eye and ocular adnexa. Ophthalmic changes can manifest in physiological and pathological abnormalities, most of which are transient and harmless; however, some cases may require therapeutic intervention or may be indicative of severe underlying disease. Our review focuses on the most common physiological ophthalmic changes associated with pregnancy and other pathological ophthalmic diseases that may develop, progress or exacerbate due to altered hormonal, immunological and metabolic effects during gestation. Furthermore, aspects of deciding the delivery mode from an ophthalmic indication, along with ocular complications related to childbirth, are described.

Keywords: pregnancy, dry eye disease, myopic shift, preeclampsia-associated retinopathy, diabetic retinopathy, caesarean section

Czakó C, Kovács I, Sándor GL, Ecsedy M, Szabó D, Szécsi D, Benkovics J, Nagy ZZs. [Pregnancy-related ocular changes and the choice of delivery mode in the presence of ophthalmological diseases]. Orv Hetil. 2021; 162(52): 2089-2099.

(Beérkezett: 2021. május 4.; elfogadva: 2021. június 7.) 


\section{Rövidítések}

APS $=$ (anti-phospholipid antibody syndrome) antifoszfolipidantitest-szindróma; $\mathrm{CNV}=$ chorioidea-neovascularisatio; $\mathrm{CSC}=$ centrális serosus chorioretinopathia DIC $=$ disszeminált intravascularis coagulopathia; hCG $=$ (human chorionic gonadotropin) humán koriongonadotropin; OCT = (optical coherence tomography) optikaikoherencia-tomográfia; $\mathrm{t}-\mathrm{PA}=$ szövetiplazminogén-aktivátor; TTP $=$ thromboticus thrombocytopeniás purpura; VEGF = (vascular endothelial growth factor) vascularis endothelialis növekedési faktor

A terhesség alatt kialakuló szemészeti eltérések a várandós nók kb. 15\%-át érintik valamilyen formában [1]. Noha ezek döntő többsége jóindulatú fiziológiás válasz a szervezet megváltozott metabolikus, hormonális és immunológiai állapotára; némely esetben súlyos szemészeti kórképek kialakulása, progressziója vagy fellángolása is bekövetkezhet, melyek azonnali diagnózist és ellátást igényelnek. Ezen változások a szem függelékeit és a szemgolyó különböző részeit egyaránt érinthetik - ı́gy a szemhéjakat, a könnymirigyet, a conjunctivát, a corneát, a retinát és a nervus opticust. Jelen közleményünk célja a terhességgel összefüggő fiziológiás és patológiás szemészeti változások bemutatása, valamint a szülésvezetés módjával kapcsolatosan felmerülő szemészeti vonatkozások ismertetése.

\section{Terhességhez kapcsolódó élettani szemészeti változások}

\section{Szembéjmelasma}

A melasma, vagy más néven chloasma, a bőr szerzett hiperpigmentációja, melyet az arc típusos érintettsége és várandós nőkben történő gyakori előfordulása (15-50\%) miatt terhességi maszknak is neveznek. Predilekciós helyei általában a napnak kitett területek, mint az orca, az orrgyök és a homlok, de előfordul a szemhéjakon is, egyes esetekben pedig csak itt jelenik meg. Hátterében az ösztrogén, a progeszteron és a melanocytastimuláló hormon hatására kialakuló fokozott melanintermelés áll [2]. A melasma kialakulásának valószínúsége genetikai hajlamtól, bőrtípustól és napfény-expozíciótól függ. A pigmentált elváltozások jellemzően a harmadik trimeszterben jelennek meg, és a tünetek a szülést követő első éven belül általában visszafejlődnek. Az elváltozás jóindulatú, malignus transzformációra nem hajlamos, az arcon történő megjelenése azonban pszichés következményeket okozhat, és hatása lehet az életminőségre. Kialakulása esetén a fény-expozíció elkerülése javasolt [3].

\section{Szemszárazság és kontaktlencse-intolerancia}

A szárazszem-betegség terhesség alatti kialakulásának pontos okai nem ismertek, de hormonális változások következtében a könnytermelés megváltozása és gyulladá- sos folyamatok beindulása valószínúsíthető a hátterében. A könnytermelés minőségi és mennyiségi zavara egyaránt okozhat szárazszem-panaszokat. Az ösztrogén és progeszteron hatására a conjunctivalis kehelysejtek száma és a könnyfilm általuk termelt mucinrétege csökken, ami a könny minőségi eltéréséhez vezethet. Ezenkívül az emelkedett ösztrogénszint miatt a könnymirigy acinussejtjeinek pusztulása következik be, ami a könnytermelés csökkenését idézi elő. Továbbá, a cornea-epithelsejtekben a gyulladásos mediátorok expressziója fokozódik, ami a szárazszem-betegség további progresszióját okozza [4]. A szemszárazság jellemzően a terhesség első trimeszterének végén jelentkezik, előfordulása a gestatiós hetek előrehaladtával megnő, és a szülést követően még hónapokig fennáll. A szárazszem-tünetek terhesség alatt gyakoriak, különböző tanulmányok a gravidák 30-80\%ában igazolták, többségük azonban panaszmentes volt [5].

A könnytermelés zavara mellett várandós nőkben a cornea érzékenysége is csökken. Ezen tényezők a kontaktlencse-viselést megnehezítik és veszélyessé tehetik, mivel szaruhártya-gyulladásra, súlyosabb esetben pedig szaruhártyafekély kialakulására is hajlamosíthatnak. A terhesség során jelentkező panaszok esetén a kontaktlencse-viselés átmeneti felfüggesztése javasolt $[1,5]$.

\section{Refraktín eltérések}

A terhesség okozta fénytörési változások kialakulásáról nem egységes az álláspont az irodalomban. A refrakció rövidlátás irányában történő elmozdulását (miopizálódás) a cornea várandósság alatt létrejövő megnövekedett vastagságának és görbületének, így a törőerő növekedésének tulajdonítják [6]. A terhesség elötti fénytöréshez képest megközelítőleg $-1,0$ dioptria eltérést írtak le a tanulmányok, mely a post partum harmadik hónapra visszatért a korábbi értékre [7]. Más vizsgálatok azonban nem találtak szignifikáns változást a refraktív értékekben a várandósság ideje alatt [8].

A cornea vastagságának, görbületének és érzékenységének fiziológiás megváltozása a terhesség alatti hormonális változások következménye. A terhesség második és harmadik trimeszterében a corneavastagság növekedését figyelték meg. A jelenség leginkább elfogadott magyarázata a várandósság során kialakuló folyadékretenció, de felmerült a nemi hormonok corneára kifejtett direkt hatása is, a cornealis stromában és endotheliumban azonosított ösztrogénreceptorok miatt [9]. A cornea görbületének fokozódását az emelkedett ösztrogén- és progeszteronszint okozta megnövekedett kollagenolitikus aktivitással magyarázzák [10].

A refrakcióban bekövetkező lehetséges változások miatt új szemüveg és kontaktlencse felírását a szülés után általában 6 hónappal ajánlott elhalasztani. A fénytörés instabilitásából, a fokozott szemszárazságból és a cornealis érzékenység csökkenéséből fakadó rosszabb sebgyó- 
gyulás miatt a lézeres látásjavító szemmütétek elvégzése a terhesség alatt és a szülést követő első évben nem javasolt [6].

\section{Szemnyomásváltozások}

A terhesség előrehaladtával a szemnyomás fokozatosan csökken, a harmadik trimeszterre a kiindulási érték mintegy 20\%-ával. Ennek hátterében több hormon hatását feltételezik: a progeszteron okozta episcleralis vénás nyomás csökkenését, a béta-hCG kiváltotta csökkent csarnokvíztermelést, valamint a szövetek megnövekedett elaszticitásáért is felelős relaxin hormon miatt a sclera rigiditásának csökkenését. Saylik és munkacsoportja szignifikáns összefüggést talált a szemnyomáscsökkenés mértéke és a magzatok száma között [11]. A szemnyomás csökkenésének ismert glaucomás nőknél van jelentősége, akiknél ez a fiziológiás hatás kedvező a betegség alakulása szempontjából. A szemnyomás a szülést követő harmadik hónapra általában visszaáll a terhesség előtti értékekre [12].

\section{A terhesség alatt megjelenő szemészeti kórképek}

\section{Praeeclampsiához társuló retinopathia}

A praeeclampsia a terhességek kb. 5\%-át érintő súlyos terhességi kórkép, és világszerte az anyai halálozás vezetô oka. Súlyos, sokszervi érintettséggel járhat, így a máj- és vesefunkció zavarával, hematológiai eltérésekkel és látáspanaszokkal. Legsúlyosabb szövődménye az eclampsiás görcsroham, mely következményes agyvérzéshez és lepényleváláshoz vezethet [13].

A praeeclampsiás nők harmadában, míg az eclampsiás esetek felében alakulnak ki szemészeti szövődmények. A leggyakoribb látáspanasz a homályos látás, de előfordulhat photopsia (fényfelvillanások), scotoma (látótérkiesések) és diplopia (kettős látás) is. A terhességi hypertoniás nók szemfenéki vizsgálata nagyon fontos, mivel a retinalis erek állapota tükrözheti a placenta ereinek állapotát. A praeeclampsiához társult retinopathia klinikai megjelenése hasonló a hypertensiv retinopathia tüneteihez. Legkorábbi és leggyakoribb szemfenéki jele a retinalis arteriolák fokális spasmusa, melyet a súlyosság előrehaladtával a retinalis arteriolák generalizált spasmusa, retinalis vérzések és exsudatumok kialakulása kísérhet (1. ábra). Súlyos esetekben papillaoedema, serosus retinaleválás és elülső ischaemiás opticus neuropathia alakulhat ki. A serosus retinaleválás a chorioidea ischaemiája következtében kialakuló subretinalis folyadékszivárgás következménye, és a leggyakrabban kétoldali bullosus retinaleválás formájában jelenik meg. Ritkán corticalis vakság alakulhat ki, amely hirtelen bekövetkező látásvesztéssel járhat, ép szemfenéki kép és pupillareakciók mellett, feltehetően a hátsó agyi vérkeringési rendszer vasoconstrictiója és az occipitalis lebeny citotoxikus oedemája miatt [14].

A retina vascularis elváltozásai korrelálnak a praeeclampsia és az eclampsia súlyosságával. Korábbi tanulmányok szerint a praeeclampsiához társult retinopathia öszszefüggést mutatott a placentaelégtelenség mértékével és
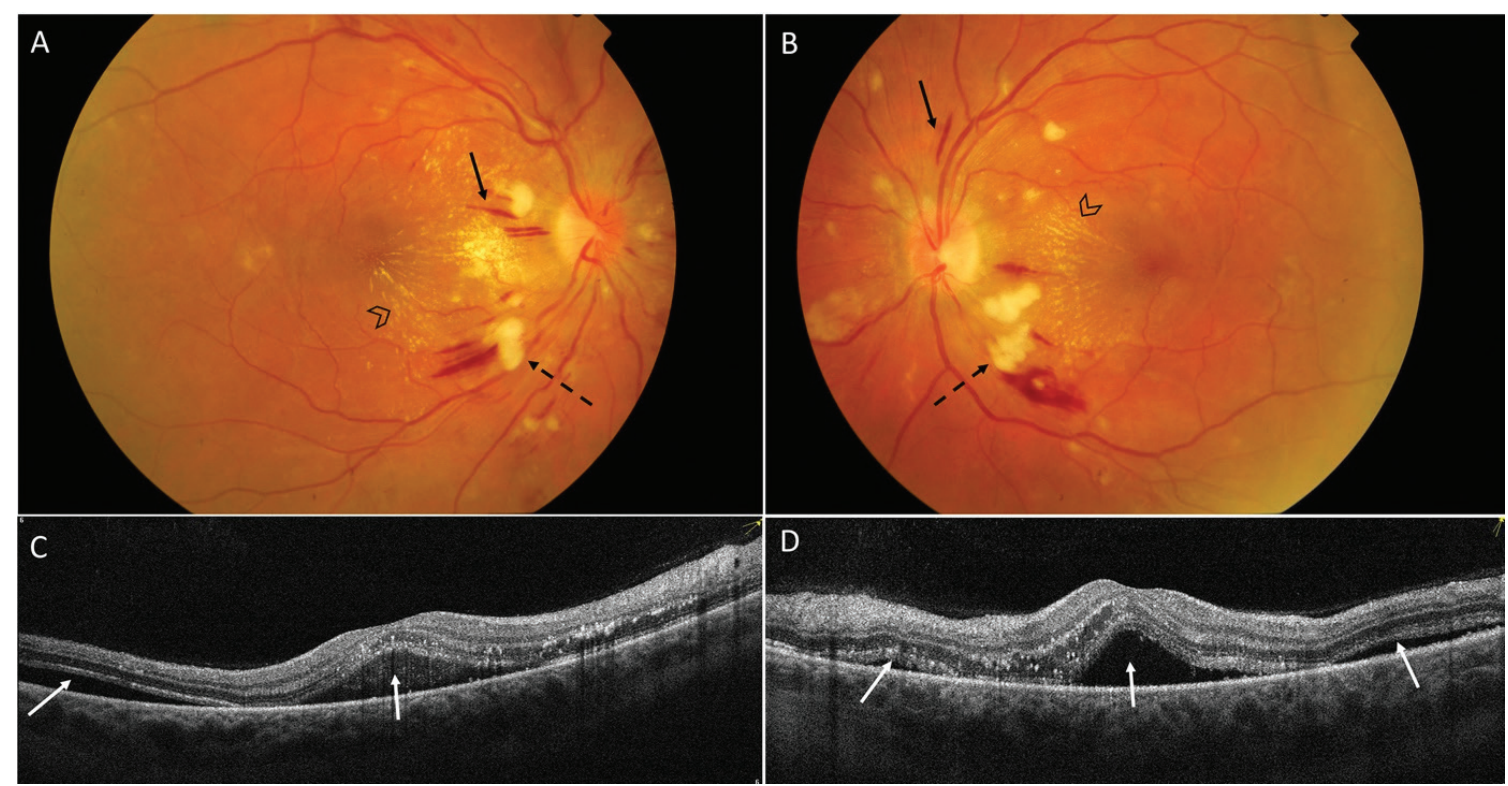

1. ábra

Jelentkezéskor 240/170 Hgmm körül mért vérnyomásértékek mellett kialakult súlyos hypertensiv retinopathia klinikai képe. A fundusfotón mindkét oldalon (A: jobb szem; B: bal szem) nasalisan elmosódott szélú, hyperaemiás papilla, a papilla körül csíkolt vérzések (fekete nyíl), gyapottépésgócok (fekete szaggatott nyíl), valamint a papillomacularis régióban radiális elrendeződésben kemény exsudatumok (hemi-macular star-fekete nyílhegy) figyelhetők meg. A macula-OCT-felvételen a jobb (C) és a bal (D) szemen egyaránt serosus retinaleválás látható (fehér nyíl: subretinalis folyadékgyülem)

OCT $=$ optikaikoherencia-tomográfia 
az intrauterin fejlődés visszamaradásával [15]. A klinikai kép társuló krónikus hypertonia, diabetes mellitus és vesebetegség esetén súlyosabb [16]. Súlyos retinovascularis elváltozások esetén a szülés mielőbbi megindítása javasolt, a gestatiós kor optimális idejének figyelembevétele mellett, a magzat életének veszélyeztetése nélkül. A szemészeti tünetek a szülést követő pár héten belül általában visszafejlődnek.

A szemfenéki vizsgálat egyszerüen kivitelezhető módszer, amely a szülész-nőgyógyászok számára segítséget nyújthat a terhességhez társult hypertoniák súlyosságának megítélésében. Mivel a retinalis erek állapota tükrözi a placenta ereinek állapotát, egyes források szerint a szemfenék állapotának megítélésével a placentaris keringési elégtelenség következtében a magzat fejlődésének visszamaradása is előre jelezhető [15].

\section{Centrális serosus chorioretinopathia}

A centrális serosus chorioretinopathia (CSC) kialakulása a harmadik trimeszterben jellemző, hátterében a terhesség alatt megemelkedő kortizolszintet valószínúsítik. Klinikailag a neuroszenzoros retina subretinalis folyadék miatti elemelkedése jellemzi. A betegek tünetei homályos látás, centrális scotoma, metamorphopsia, micropsia, színlátászavar és kontrasztérzékenység-csökkenés formájában nyilvánulhatnak meg. A kórkép diagnózisa macula-OCT-vel állítható fel, a retina szerkezeti felvételén a neuroszenzoros retina és a retinalis pigmentepithelium között kialakuló folyadékgyülem jól azonosítható (2. ábra). A várandósság során jelentkező CSC-ben gyakori a fibrinosus subretinalis exsudatumok megjelenése. A betegség terápiát nem igényel, a folyadék spontán felszívódása várható a szülést követô pár hónapon belül, azonban a további terhességek során a betegség relapsusra hajlamos [17].

\section{Vascularis occlusiv betegségek}

A szemfenéki érelzáródásokkal járó szemészeti kórképek a terhesség alatt fennálló, fiziológiásan fokozott véralvadási hajlam következtében alakulhatnak ki. Önálló, háttérbetegség nélküli megjelenésük ritka, ebben az esetben artériás érelzáródásokat gyakrabban figyeltek meg, mint vénás érelzáródásokat. Gyakoribb a diagnosztizálatlan, várandósság hatására súlyosbodó vagy terhességgel kapcsolatosan megjelenő szisztémás thrombophiliák melletti kialakulásuk [18].

A disszeminált intravascularis coagulopathia (DIC) súlyos véralvadási zavarral járó kórkép, mortalitása 2050\%. Terhességi komplikációként korai lepényleválás, praeeclampsia/eclampsia, magzatvíz-embolia, intrauterin fertőzés és a magzat intrauterin elhalása következtében alakulhat ki. Patofiziológiailag a kiserek thrombosisa, majd fokozott vérzékenység és szövetnecrosis jellemzi. Szemészetileg a choriocapillarisok érintettsége miatt kialakuló chorioideaischaemia és -vérzés serosus retinaleválást okozhat. A szemészeti tünetek a DIC kezelésével általában visszafejlődnek, maradványtünetek azonban előfordulhatnak [19].

A thromboticus thrombocytopeniás purpura (TTP) a thromboticus microangiopathiák közé sorolható betegség, előfordulása terhesség alatt megnő. Klinikailag thrombocytopenia, microangiopathiás haemolyticus anaemia, fluktuáló idegrendszeri tünetek, veseelégtelenség és láz jellemzi. Szemészeti tünetek a TTP eseteinek 10\%-ában megfigyelhetők, a retinalis arteriolák szúkuülete, retinalis vérzések és exsudatumok, papillaoedema és serosus retinaleválás formájában. Plazmaferézis elvégzése után a retinaleválás visszafejlődését figyelték meg pár napon belül [20].

Az antifoszfolipidantitest-szindróma (APS) a haemostasis komplex zavarával járó szisztémás autoimmun betegség, mely habituális vetélést, artériás és vénás thrombosist és thrombocytopeniát okozhat. A betegek 15-88\%-ában alakul ki különböző szemészeti érintettség; az elülső szegmentumban conjunctivalis teleangiectasiák, episcleritis, keratitis és iritis, míg a hátsó szegmentumban retinalis vasculitis, retinalis artériás és vénás thrombosis, posterior scleritis és serosus retinaleválás jelentkezhet. Bizonyos esetekben a szemészeti tünetek hívják fel a figyelmet a szisztémás kivizsgálás szükségességére; a kórkép diagnózisával életet veszélyeztető szövődmények kialakulása előzhető meg [21].

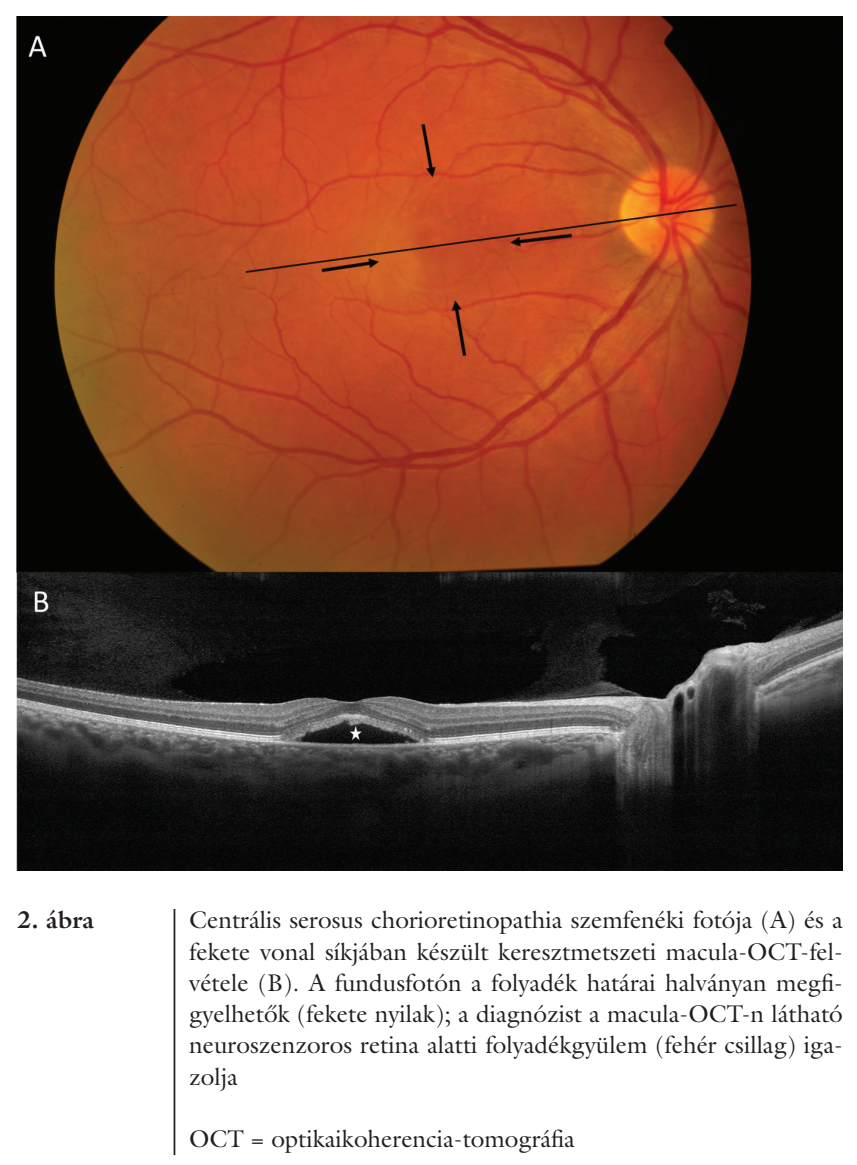




\section{Korábbi szembetegségek terhesség hatására bekövetkező progressziója vagy fellángolása}

\section{Diabeteses retinopathia}

A diabeteses retinopathia a megelőzhető vakság egyik vezető oka a fejlett országokban a keresóképes lakosság körében. A kórkép két fó stádiuma a nonproliferatív (enyhe, mérsékelt, súlyos) és a proliferatív diabeteses retinopathia; az utóbbi esetben már kóros érújdonképződések jelennek meg a szemfenéken (3. ábra). A diabeteses retinopathia látást veszélyeztető szövődménye egyrészt a diabeteses maculopathia - mely magában foglalja a diabeteses maculaoedemát és a diabeteses macularis ischaemiát -, másrészt a proliferatív forma komplikációjaként kialakuló üvegtesti vérzés, trakciós retinaleválás és neovascularis glaucoma. A retinopathia szürésével és időben történő felismerésével a progresszió lassítható, a látásromlást okozó szövődmények kialakulása megelőzhető [22].

A diabeteses retinopathia progressziója a terhesség alatt felgyorsulhat. A diabeteses kisérkárosodás súlyosbodását szisztémás és hormonális változásoknak tulajdonítják - ilyen a retinalis capillaris véráramlás fokozódása okozta endothelsejt-károsodás és a progeszteron hatására megnövekedett vascularis endothelialis növekedési faktor (VEGF-) termelés. A progresszió mértéke függ a diabetes fennállási idejétől, a retinopathia stádiumától a terhesség kezdetén, a glikémiás kontrolltól és a hypertonia jelenlététól [23].

A várandósság alatt megjelenő, gestatiós diabeteses nők és a diabeteses retinopathia kialakulása között nem figyeltek meg összefüggést. Ez nem meglepő, hiszen a diabeteses retinopathia kialakulásának legfontosabb rizikófaktora a diabetes fennállási ideje. Az ismert diabetes mellitusos, de retinopathia nélküli betegek 10\%-ánál alakultak ki enyhe nonproliferatív tünetek, míg a mérsékelt és súlyos nonproliferatív diabeteses retinopathiás esetek közel 55\%-ában figyeltek meg további progressziót a terhesség során. A proliferatív forma kialakulása a kezdeti enyhe nonproliferatív diabeteses retinopathiás szemek 6\%-ában, míg a mérsékelt és súlyos nonproliferatív diabeteses retinopathia eseteinek 30\%-ában következett be. A progresszió a szülést követően az esetek nagy részében visszafejlődött [24].

A proliferatív stádiumban szemfenéki lézerkezelés elvégzése szükséges az újonnan képződött erek regreszsziója céljából, mely várandósság alatt is biztonsággal elvégezhető. Súlyosabb esetben a fragilis érújdonképződésekből vérzés indulhat ki, következményes üvegtesti vérzés kialakulásával. Ennek spontán felszívódása várható, stagnáló esetekben azonban üvegtesti mútét (vitrectomia) elvégzése válhat szükségessé a szülést követően. Sürgősségi vitrectomia fibrovascularis membrán

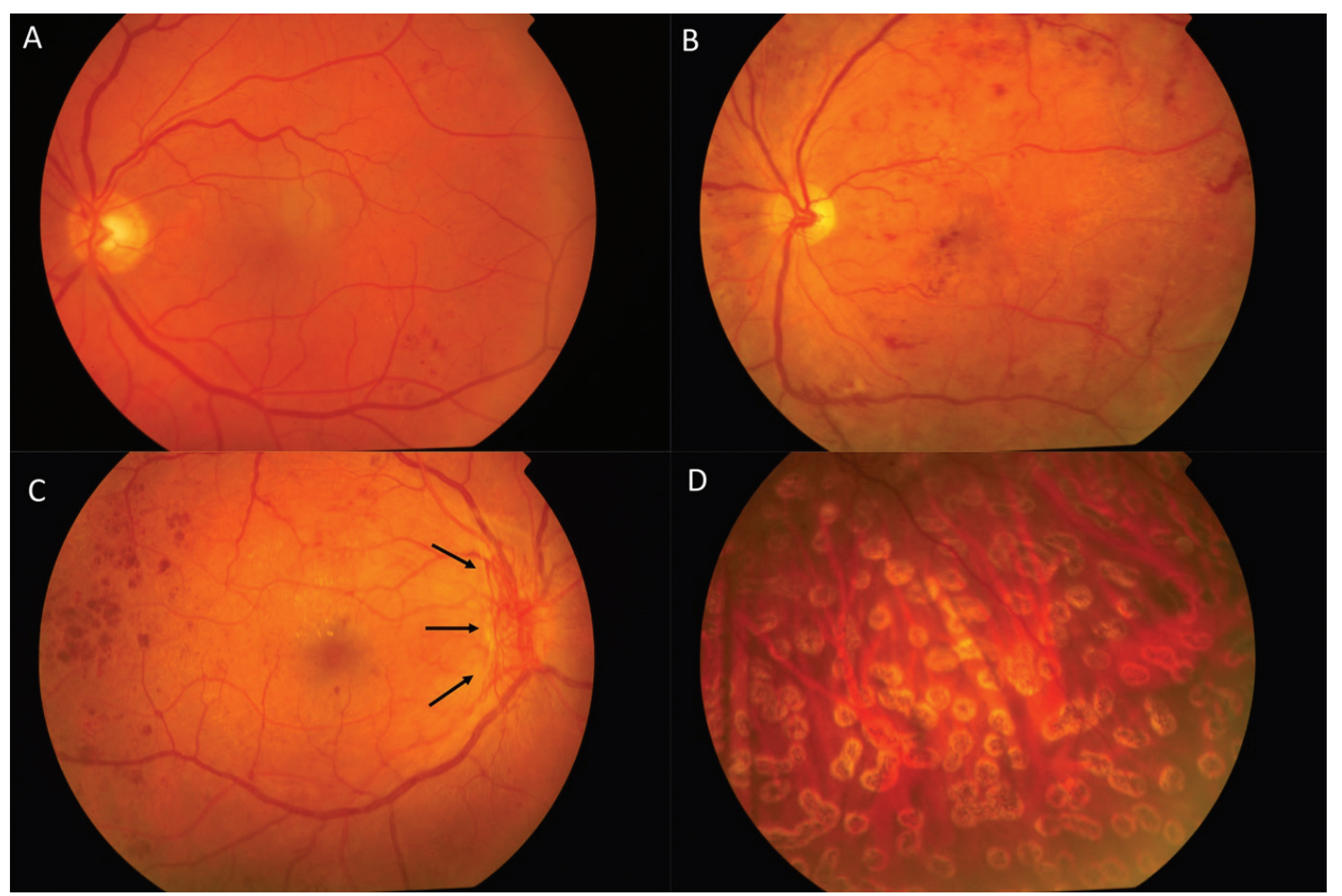

3. ábra

Diabeteses retinopathia különböző stádiumainak szemfenéki felvételei. Mérsékelt nonproliferatív diabeteses retinopathiánál (A) a fundus több kvadránsát érintően microaneurysmák és pontszerú vérzések figyelhetők meg; súlyos nonproliferatív stádiumban (B) fundusszerte microaneurysmák, pontszerú és tócsás vérzések, elzáródott erek, valamint gyapottépésgócok láthatók. Proliferatív diabeteses retinopathiában (C) a papilla területében szabálytalan, kóros érújdonképződések jelennek meg (fekete nyilak). A D ábra a szemfenéki lézerkezelés elvégzése után a periférián látható pigmentálódó lézergócokat ábrázolja 
kontrakciója esetén indikált, ha a trakciós retinaleválás a centrális látást veszélyezteti [25].

A diabeteses maculaoedema a diabeteses retinopathia bármely stádiumában kialakulhat, és jelentős látásromlással járhat. A macula centrális területén kívül eső, fokális szivárgással járó maculaoedemát kezelhetjük szemfenéki lézerterápiával, mert így a célzott lézerkezelés pontos helye megállapítható. A macula centrumát érintő esetekben és jelentős látásromlás esetén intravitrealis anti-VEGF-injekciók adása javasolt, azonban a magzat fejlődő érrendszere miatt várandósoknál ennek elkerülése indokolt. A fogantatást az utolsó anti-VEGF-injekció beadása után 3 hónappal ajánlott tervezni. Azokban az esetekben, amikor az anti-VEGF-terápia nem kerülhetó el, a ranibizumabinjekció választása előtérbe helyezendő, mivel a vérplazma VEGF-szintjét kevésbé csökkenti a bevacizumabhoz és az aflibercepthez képest [26]. Alternatívaként intravitrealis szteroid adása megfontolandó, melynek alkalmazása miatt kialakult congenitalis malformációról ez idáig nem számoltak be az irodalomban. Ennek ellenére alkalmazásuk terhességben elóvigyázatossággal kell hogy történjen [23].

A diabeteses nók fogantatás előtti betegtájékoztatása nagyon fontos a szülész-nőgyógyász, a diabetológus és a szemorvos részéról egyaránt. A diabetes szemészeti szövődményeinek kialakulása a terhesség során az anyai életkor növekedésével exponenciálisan megnő, így a harmadik évtizedet követően kiemelt jelentősége van a várandósságra történő felkészülésnek. A terhesség előtt a vércukorháztartás szoros ellenőrzése és szigorú rendezése javasolt. A diabeteses retinopathia előrehaladottabb stádiumai esetén a kisérkárosodás nagyobb mértékú progressziója várható, ezért a fogantatás előtt a szemészeti status stabilizálása ajánlott. Irodalmi adatok szerint a prekoncepcionális szemfenéki lézerkezelés $50 \%$-kal csökkentette a diabeteses retinopathia progresszióját, így súlyos nonproliferatív vagy proliferatív diabeteses retinopathia eseteiben a teherbe esés előtt a lézerterápia elvégzése javasolt [24].

Diabeteses várandós nőknél a szemfenéki eltérések jelenlétének ismeretétől függetlenül javasolt egy kiindulási szemészeti vizsgálat elvégzése a terhesség megállapítását követően. Diabeteses retinopathia nélküli vagy enyhe nonproliferatív diabeteses retinopathia esetén a szemészeti kontroll látáspanaszok hiányában elegendő a harmadik trimeszterben. Mérsékelt nonproliferatív diabeteses retinopathia fennállásakor javasolt a szemészeti vizsgálat trimeszterenkénti, súlyos nonproliferatív diabeteses retinopathia esetén kéthavi, míg proliferatív retinopathia esetén havi rendszerességgel történő elvégzése [27].

A retinopathia diagnózisa pupillatágításban végzett szemfenéki vizsgálattal történik. A pupillatágító szemcseppek alkalmazása könnypontkompresszióval kell, hogy történjen, a hatóanyag szisztémás keringésbe történő jutásának minimalizálása céljából. Habár a hagyományos érfestéses vizsgálathoz alkalmazott fluoreszcein kontrasztanyag nem bizonyult teratogénnek, elvégzéséhez a terhesség relatív kontraindikációt képez. A szemfenéki érhálózat megjelenítésére az utóbbi években kifejlesztett új diagnosztikai eszköz az OCT-angiográfia, mely gyorsan és egyszerüen kivitelezhető, és a vérkeringés ábrázolásához nem igényel kontrasztanyag-beadást, így várandósoknál is biztonsággal elvégezhető [22].

\section{Hypophysisadenoma}

A terhesség alatt a hypophysis fiziológiásan is megnagyobbodik az ösztrogén és a progeszteron hatására stimulálódó prolaktintermelő sejtek hyperplasiája miatt. A laktotrop sejtek megnagyobbodása a terhesség elején kezdődik, és a szülést követő 2 héten, de legkésőbb 6 hónapon belül visszafejlődik. A hypophysis mérete az eredeti méret $120 \%$-át is elérheti [28]. A reproduktív korban lévő nők leggyakrabban előforduló hypophysisadenoma-típusa a prolactinoma. Mivel a prolactinoma jellemzően infertilitással és reproduktív múködészavarral jár, a terhesség alatt ritkán fordul elő diagnosztizálatlanul. A mérete alapján micro- és macroadenomákat különböztetünk meg, melyek közül az utóbbiak mérete a várandósság során megnövekedhet. Általában sem a hypophysis fiziológiás növekedése, sem a hypophysisadenoma megnagyobbodása nem jár tünetekkel, ha viszont egy bizonyos nagyságot elér, és a chiasma opticumot komprimálja, bitemporalis látótérkiesés, látóélességcsökkenés és diplopia alakulhat ki. Ebben az esetben gyógyszeres terápiára van szükség, bromokriptin, kabergolin vagy kinagolid adásával, a konzervatív terápiára nem reagáló esetekben azonban sebészi kezelés is szükségessé válhat [29]. A szülést követően a hypophysisadenomák regrediálnak, így hosszú távú látáspanaszok nem alakulnak ki. Ismert hypophysisadenoma esetén javasolt havonta szemészeti vizsgálat elvégzése, látótérvizsgálattal és papilla-OCT-vel kiegészítve.

\section{Idiopathiás intracranialis hypertonia (pseudotumor cerebri)}

A pseudotumor cerebri ismeretlen etiológiájú kórkép, mely fokozott intracranialis nyomással jár, térszúkítő folyamat és neurológiai góctünet nélkül. Általában túlsúlyos, reproduktív korú nőkben jelenik meg a harmincas éveik környékén. Incidenciája ebben a populációban 100000 lakosra vonatkoztatva évente 19,3 új eset. Terhességben előfordulása megnő, már meglévő esetben pedig tovább súlyosbodhat, jellemzően az első két trimeszterben. Leggyakoribb tünetei a fejfájás (90\%) és a szemészeti panaszok (70\%) kialakulása. Az utóbbiak közé tartozik a rövid ideig tartó látásvesztés, scotomák, retrobulbaris fájdalom és a diplopia. Az átmeneti látásvesztés általában legfeljebb 30 másodpercig tart; hátterében a nervus opticus ideiglenes keringészavara áll, és sokszor a páciens ortosztatikus helyzetéhez kötődik. 
A látótérkiesésekre a fiziológiás vakfolt kiszélesedése és a perifériás látótér beszúkülése lehet jellemző. A kettős látás a fokozott intracranialis nyomás következtében a nervus abducens érintettsége esetén alakul ki. A szemfenéki vizsgálaton sokszor kétoldali papillaoedema figyelhető meg, de egyoldali esetek is előfordulhatnak. A látásromlás az esetek nagy részében reverzibilis, 25\%-ban azonban opticus atrophia alakulhat ki, mely maradandó látásromlással jár [30]. Tekintettel a terhesség alatti fokozott thrombosiskockázatra, sürgős képalkotó vizsgálat elvégzése szükséges a vénás sinusthrombosis és a térszúkítő folyamatok kizárására. A kezelés célja elsősorban a látásvesztés megelőzése. A leghatékonyabb terápia a testsúly csökkentése (terhességben megfelelö testsúlykontroll) és a lumbálpunkció elvégzése. Az elsődlegesen választandó gyógyszeres terápia karboanhidráz-bénító diuretikum, az acetazolamid szájon át történő szedése. Megjegyzendő, hogy terhességben történő biztonságos adásáról kevés adat áll rendelkezésre, így lehetőség szerint ennek elkerülése javasolt [31].

\section{Ocularis toxoplasmosis}

A Toxoplasma gondii okozta ocularis toxoplasmosis a posterior uveitisek leggyakoribb oka a világon. A kórkép recidívára hajlamos, a betegek kétharmadában jellemző életük során a relapsus. Ennek oka a parazita trophozoita formájának szöveti cisztából való kiszabadulása, melynek bizonyos antigénjei ellen kialakult immunológiai reakció gyulladásos chorioretinitist indukál. A Toxoplasma-chorioretinitis típusos klinikai képe a fehér, vattaszerú chorioretinalis laesio jelenléte a szemfenéken, üvegtesti gyulladás (vitritis) kíséretében (4. ábra). A szemészeti tünetek általában a vitritisből adódnak - homályos látás és úszkáló homályok formájában -, ritkábban a macula vagy a látóidegfó érintettségéből. A látásromlás maradandó lehet a macula területében kialakuló heg vagy az opticus atrophia miatt. A latens ocularis toxoplasmosis terhesség alatt az immunrendszer változásainak következtében reaktiválódhat és congenitalis toxoplasmosissal járhat [32]. A reaktiválódó laesio a korábbi chorioretina-

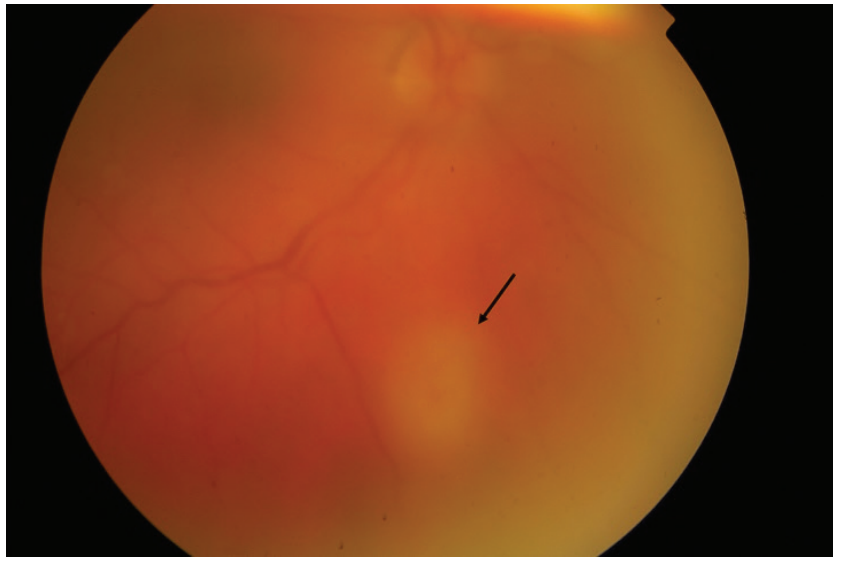

4. ábra

Ocularis toxoplasmosis szemfenéki fotóján a beszűrt üvegtesten keresztül a fehéres chorioretinalis gyulladásos laesio (fekete nyíl) áttúnik - „fényszóró a ködben” jelenség

lis heg határában jelenik meg. Terhességben bekövetkezô toxoplasmosis esetén a makrolid antibiotikumok családjába tartozó spiramicin szájon át történő szedése javasolt.

Az ocularis toxoplasmosissal ellentétben a gyulladásos eredetû (sarcoidosis, rheumatoid arthritis, spondylarthropathia asszociálta) uveitisek esetén a terhesség jótékony hatású, a gyulladásos epizódok száma általában csökken, ami feltehetően az emelkedett kortikoszteroidszintnek köszönhető. A szülést követően azonban a betegség fellángolása várható [33].

\section{A szülésvezetés módjának szemészeti kérdései}

A WHO felmérése szerint 2015-ben a születések 21\%-a császármetszéssel történt, ami több mint kétszeres arány a két évtizeddel ezelőtti adatokhoz képest [34]. Habár a beavatkozás életmentő lehet, számtalan szövődménnyel járhat mind az anya, mind pedig a magzat tekintetében. A császármetszésnek az anyát érintő komplikációi között szerepel a fertőzés, a vérzés, az anesztéziai és pszichés szövődmények, nem beszélve a császármetszéssel világra
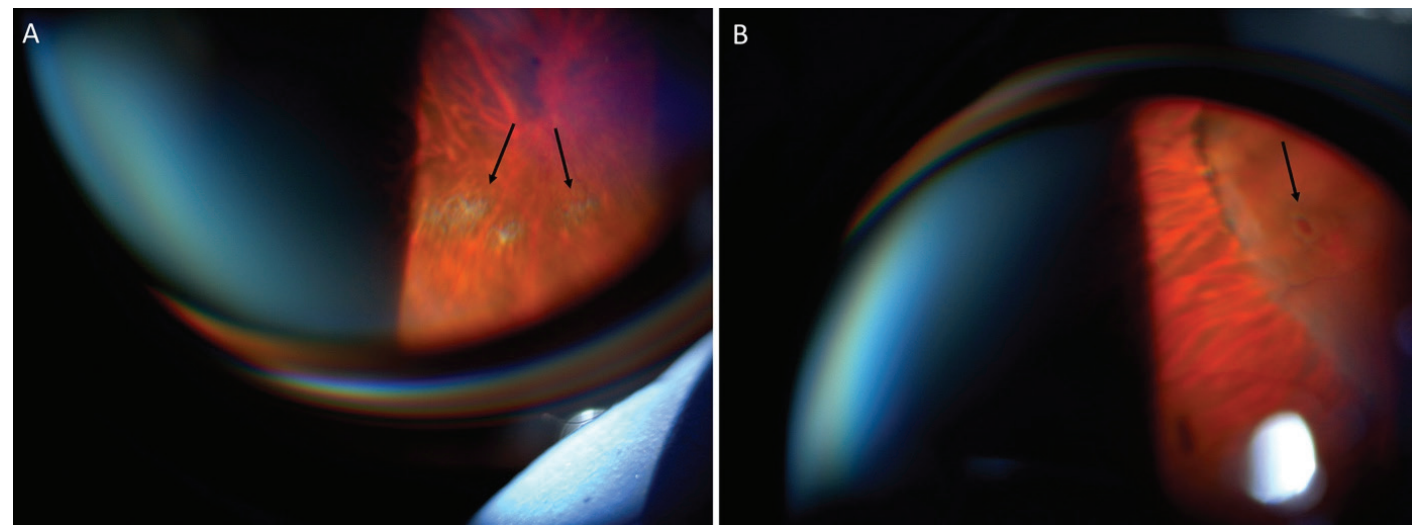

5. ábra $\quad$ Fundusvizsgálat Volk-lencsén keresztül: a retina perifériáján csigamászás-degeneráció (A: fekete nyilak), valamint kerek lyuk (B: fekete nyíl), környezetében demarkációs vonallal határolt retinaleválás látható 
hozott újszülöttek gyakoribb légzésproblémáiról [35]. Mindezek miatt évek óta folynak erőfeszítések annak megértésére, hogy mi mozgatja ezt a tendenciát, és hogyan azonosítsák azokat a nőket, akik szükségtelenül esnek át császármetszésen.

Irodalmi adatok szerint a szemészeti betegségek a császármetszés leggyakoribb nem szülészeti indikációi. Egy korábbi felmérés alapján a császármetszések 2\%-a szemészeti indikáció miatt történik [36]. A császármetszést indikáló leggyakoribb szemészeti kórképek a fénytörési hibák (rövidlátás vagy myopia) (57\%), a retina különböző betegségei (retinopathiák) (20\%), a korábban bekövetkezett retinaleválás (7\%) és a zöld hályog (5\%) voltak [35].

Az 1990-es években önmagában a rövidlátás megléte alapján, a szemfenék vizsgálata nélkül - így a retina állapotától függetlenül - döntöttek a hüvelyi szülés második szakaszának múszeres befejezéséről (fogóműtét, vákuumextrakció) vagy a császármetszés elvégzéséről. Az indikáció oka a rhegmatogen retinaleválástól való félelem volt, melyet a Valsalva-manőver okozta intraocularis nyomás ingadozása miatt az üvegtesti határhártya leválási kockázatának és a myopiában gyakoribb előfordulású retinalis degenerációk és lyukak együttes következményének tulajdonítottak (5. ábra). A 2000-es években gyakoribbá váltak a szülést megelőző szemészeti konzultációk, melyek hatására már a retina vizsgálata és a retinán talált eltérések alapján határozták meg myopiás várandósokban a szülésvezetés módjának javaslatát. Ennek következtében a császármetszés szemészeti indikációból történő elvégzésének gyakorisága is lecsökkent [37].

Napjainkban a myopiás nók nagy száma megy keresztül továbbra is szükségtelenül császármetszésen, főleg a kelet-európai országokban. Egy 10 éves követési idővel rendelkező tanulmányban azt találták, hogy a rövidlátó nők másfélszer gyakrabban szülnek császármetszéssel, mint a nem myopiás nók [38]. Az irodalomban fellelhető források szerint azonban a hüvelyi úton történő szülés nincs összefüggésben a retinaleválás kialakulásával myopiás nókben, a dioptria értékétól függetlenül [1,6].

A szemészeti rendeléseken a myopiás várandósok gyakran jelennek meg a császármetszés eldöntésének kérdésével kapcsolatban. Chiu és mtsai 2015-ben felmérést végeztek a szülész-nőgyógyászok és a szemészek körében a retinaleválás kockázati tényezőivel rendelkező nők esetében a szülésvezetés módjának kérdéséről. A szülész-nőgyógyászok 34\%-a, míg a szemészek csupán 4\%-a tartotta indokoltnak az elektív császármetszés szemészeti indokból történő elvégzését [39]. Egy másik felmérésben a szülész-nőgyógyászok 0,6\%-a és a szemészek 73\%-a javasolta a hüvelyi szülést különböző szemészeti betegségek esetén [35].

Rövidlátó nőknél a hüvelyi szülést megelőző profilaktikus szemfenéki lézerkezelés elvégzésének indikációja vitatott. Landau tünetmentes, retinaleválásra hajlamosító perifériás retinalaesiók eseteiben nem javasolta a lézerkezelés elvégzését [40], ezzel szemben más tanulmányok annak kivitelezését indikálták a perifériás degenerációk és lyukak jelenlétében. A szemfenéki lézerkezelés a perifériás degenerációk körül történik; a fotokoagulációs hatásra a retinalis pigmentepithelium destrukciója és a kezelést követően 1-2 héttel chorioretinalis adhéziók kialakulása következik be. Mindez elhatárolja az ép retinaszövetet a kóros területtől, és védősáncként előzi meg a degeneratív laesiókból induló esetleges retinaleválást. A profilaktikus lézerkezelés indikációját a szemész dönti el a perifériás retinadegeneráció típusa, klinikai jellemzői és az anamnézis alapján; elsősorban rácsos és csigamászás-degeneráció esetén végzik el, így csökkentve a szülés kapcsán kialakuló ideghártya-leválás kockázatát [40-42].

Pillanatnyilag nem áll rendelkezésünkre konszenzus a szülésvezetés módjának szemészeti indokból történő meghatározásáról. Ezzel kapcsolatosan egyedül a Lengyel Szemészeti és Szülészeti Szakmai Kollégium tett közzé irányelvet 2018-ban, mely szerint a következő esetekben ajánlott a császármetszés elvégzése: myopiás subretinalis chorioidea-neovascularisatio $(\mathrm{CNV})$, proliferatív diabeteses retinopathia, előrehaladott glaucoma súlyos látótér-károsodásokkal, előrehaladott vagy akut keratoconus, bizonyos szemészeti posztoperatív esetek és corticalis vaksággal vagy serosus retinaleválással szövődött eclampsia [43]. A myopiás CNV nagy fokban rövidlátó szemek ritka szövődménye, melyet a maculatájon kialakuló kóros erek jellemeznek. Tulajdonságuk, hogy nagyon fragilisak, könnyen megrepednek, subretinalis vérzést és súlyos centrális látásromlást okozva. Proliferatív diabeteses retinopathiában hasonlóan a sérülékeny érújdonképződések mint potenciális vérzésforrások magyarázzák az ellenjavallat okát. A szülés kitolási szakaszában alkalmazott Valsalva-manőver miatt az intraocularis nyomás hirtelen megnő, és az ocularis perfusio lecsökken. Habár ez a jelenség a szülést követően normalizálódik, súlyos és rosszul karbantartott glaucoma esetén ennek a szakasznak a lerövidítése javasolt a retinalis ganglionsejtek további veszteségének elkerülésére. Előrehaladott keratoconusnál a megnövekedett intraocularis nyomás miatt a cornea elvékonyodott területein a Descemet-membrán repedése, akut hydrops corneae és szélsőséges esetben spontán perforáció kialakulása magyarázza a császármetszés indikációját [44].

A jelenlegi álláspont szerint sem a szülész, sem pedig a szemorvos nem dönthet egyedül a császármetszés szemészeti indikációból történő elvégzéséről. Protokoll hiányában minden felmerülő esetben egyedi elbírálás és interdiszciplináris együttmúködés szükséges a hüvelyi úton történő szülés ellenjavallatának felállítására.

\section{A szüléshez kapcsolódó szemészeti szövődmények}

\section{Subconjunctivalis vérzés}

A szüléssel összefüggésben kialakult leggyakoribb szemészeti szövődmény a subconjunctivalis vérzés, mely az esetek mintegy 10\%-ában megfigyelhető. A vérzés a kis 


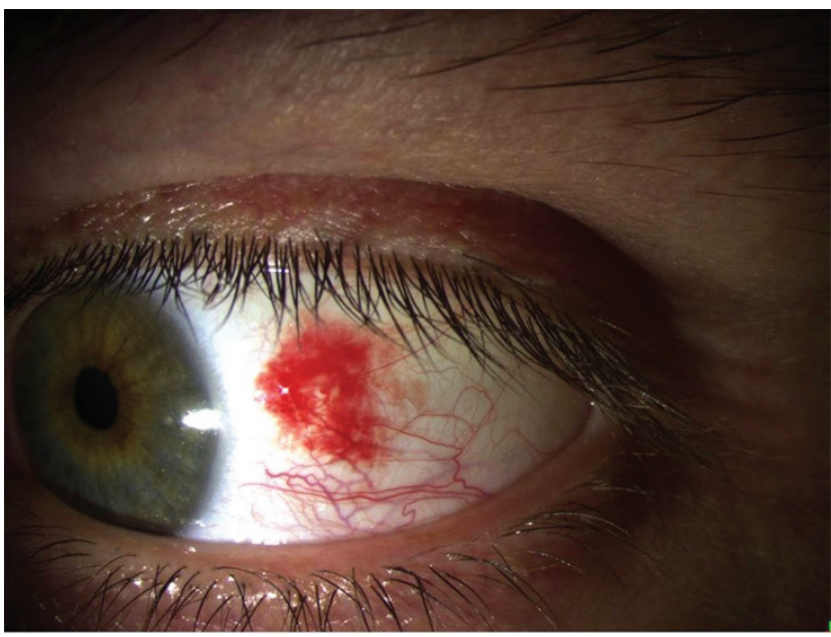

6. ábra

Subconjunctivalis suffusio réslámpás felvétele. A vérzés felszivódása néhány héten belül terápia nélkül bekövetkezik

conjunctivaerek rupturája és a subconjunctivalis kötőszövetben történő szétterjedése következtében alakul ki (6. ábra) [45]. A kórkép ártalmatlan, felszívódása néhány hét alatt spontán bekövetkezik, teendőt nem igényel.

\section{Valsalva-retinopathia}

A szülés során megemelkedő intrathoracalis és intraabdominalis nyomás hatására az intraocularis vénás nyomás megnő, ami a felszíni retinalis capillarisok megrepedését okozhatja. A Valsalva-retinopathia a szülés ritka szemészeti komplikációja, mely jellemzően egyoldali; főként a macula területén kialakuló felszíni retinalis vérzésekben nyilvánul meg, hirtelen jelentkező fájdalmatlan látásromlás formájában. Az esetek többségében a vérzések enyhék, és néhány hónap alatt spontán felszívódnak. Nagy mennyiségú praemacularis vérzés esetén azonban a vérzés tartósan fennálló toxikus hatása miatt a fotoreceptor-

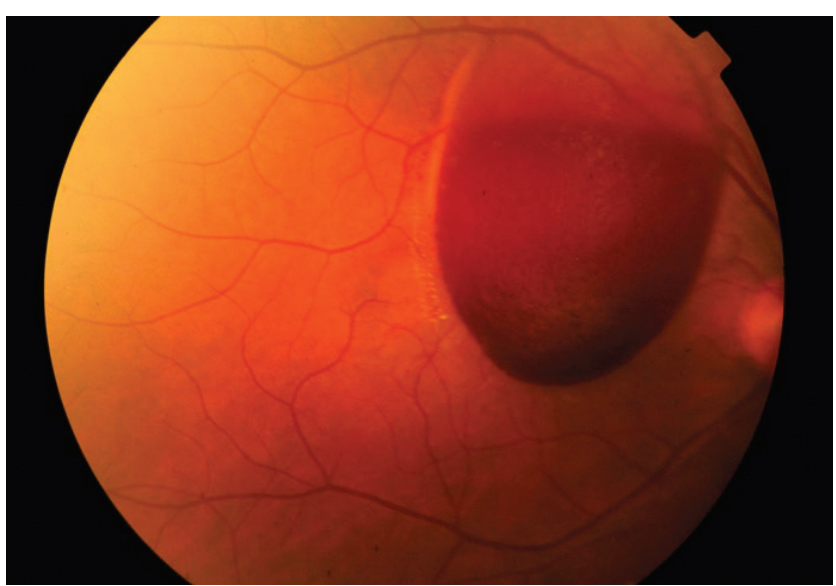

7. ábra

25 hetes gravida hányást követően kialakult, jobb oldali súlyos látásromlásának (látóélesség a jobb szemen: 1,5 méter ujjolvasás) hátterében nagy mennyiségű praemacularis vérzés igazolódott a szemfenéki vizsgálaton és retinalis pigmentepithelium károsodása, valamint epiretinalis membrán alakulhat ki. Ebben az esetben a vérzés felszívódásának gyorsítására lézeres membranotomia vagy pars plana vitrectomia során a vérzés területébe injektált szövetiplazminogén-aktivátor ( $\mathrm{t}-\mathrm{PA}$ ) adása megfontolandó [46]. Irodalmi adatok szerint a Valsalvaretinopathia kiújulásra nem hajlamos, így nem kontraindikálja a hüvelyi úton történő további szüléseket [47]. A kórkép a szülés kitolási szakaszán kívül a terhesség alatti, eróltetett hányáshoz kapcsolódóan is kialakulhat (7. ábra).

\section{Purtscher-retinopathia}

A Purtscher-retinopathia a szülést követő 24 órán belül kialakuló ritka kórkép. A betegség oka ismeretlen, de hátterében a praecapillaris arterioláknak a komplementmediált leukocytaaggregáció következtében kialakuló occlusióját valószínúsítik. Klinikailag a leggyakrabban kétoldali megjelenésû retinalis vérzések, oedema és gyapottépésgócok jellemzik a szemfenéken, döntően a látóidegfö körüli elrendezésben [48]. Pathognomicus jele a fehér ischaemiás foltok (Purtscher's flecken) jelenléte, melyek az arteriolák körül kialakuló poligonális fehér területek, szélükön tiszta zónával. Ez a morfológia annak köszönhető, hogy az occlusio a praecapillaris szinten történik, az arteriolák körül megtartott perfusióval, ellentétben az ettől proximalisabban kialakuló elzáródással, mely a retina konfluáló fehér területként megjelenő ischaemiáját idézi elő (mint például szemfenéki artériás ágelzáródásban). A panaszok látásromlás formájában, különböző mértékben jelenhetnek meg, és az enyhe látóélesség-csökkenéstől a kézmozgáslátásig terjedhetnek. Terápia nélkül a tünetek 1-3 hónapon belül spontán visszafejlődnek [49].

\section{Sheehan-szindróma}

Jelentős vérvesztéssel járó szülések után a hypophysis ischaemiás necrosisa jöhet létre. Kialakulásában meghatározó szerepe lehet a hypophysis terhesség alatti megnagyobbodásának és hypervascularisatiójának, mely a hypovolaemiás sokkra érzékenyebbé teszi az agyalapi mirigyet. A hypophysisnek a látópályát érintő akut kompressziója következtében a szemészeti panaszok a kórkép első tünetei lehetnek, hirtelen kialakuló látásromlás és látótérkiesés (jellemzően bitemporalis quadranopia) formájában, erôs fejfájás kíséretében. A sinus cavernosus közeli elhelyezkedése miatt a III., a IV. és a VI. agyideg érintettsége, szemizombénulások és kettős látás alakulhat ki. A kórkép korai diagnózisa és megfelelő ellátása a maradandó látásromlás megelőzése céljából is fontos. A hypophysis károsodása panhypopituitarismust okozhat, a diagnózis felállítása akut tünetek hiányában azonban sokszor a szülést követően évekkel történik meg. Panhypopituitarismus esetén a csökkent hormontermelés élethossziglan történő pótlása válik szükségessé [50]. 


\section{Következtetés}

A várandóssággal összefüggésben kialakuló szemészeti panaszok általában ártalmatlanok, és a szülést követően spontán visszafejlődnek - mint a szemhéjak fokozott pigmentációja, a szemszárazság és a fénytörés myopia irányában történő eltolódása. Ennek ellenére azonban súlyos, akár látást veszélyeztető szemészeti betegségek is megjelenhetnek, a terhességhez kapcsolódóan kialakuló szisztémás betegség szemészeti megnyilvánulásaként vagy korábban fennálló szembetegség súlyosbodásaként (1. táblázat). A szemészeti vizsgálat a szülész-nőgyógyászok számára fontos információt nyújthat bizonyos terhességasszociált háttérbetegségek kialakulásakor, mint praeeclampsiánál a kórkép súlyosságának megítélésében. Cukorbeteg nőknél a diabeteses retinopathia terhességhez köthető, jelentősen felgyorsult progressziója miatt fontos felhívni a figyelmet a szoros diabetológiai és szemészeti kontroll szükségességére, a teherbe esés tervezé-

1. táblázat | Terhességhez és szüléshez kapcsolódó szemészeti változások

\begin{tabular}{|c|c|c|}
\hline \multicolumn{3}{|c|}{ Terhesség alatti fiziológiás szemészeti változások } \\
\hline Érintett részek & Klinikai eltérések & Tünetek \\
\hline Szemhéjak & Szemhéjmelasma & Fokozott pigmentáció \\
\hline \multirow[t]{2}{*}{ Könnyfilm } & Csökkent könnytermelés & Szemszárazság \\
\hline & $\begin{array}{l}\text { Conjunctivalis kehelysej- } \\
\text { tek károsodása }\end{array}$ & $\begin{array}{l}\text { Kontaktlencse-intole- } \\
\text { rancia }\end{array}$ \\
\hline \multirow[t]{3}{*}{ Cornea } & $\begin{array}{l}\text { Csökkent corneaérzé- } \\
\text { kenység }\end{array}$ & $\begin{array}{l}\text { Kontaktlencse-intole- } \\
\text { rancia }\end{array}$ \\
\hline & & Lassabb sebgyógyulás \\
\hline & $\begin{array}{l}\text { Fokozott corneavastagság } \\
\text { Fokozott corneagörbület }\end{array}$ & $\begin{array}{l}\text { A fénytörés változása } \\
\text { (miopizálódás) }\end{array}$ \\
\hline Szemnyomás & \multicolumn{2}{|l|}{ Csökkent szemnyomás } \\
\hline \multicolumn{3}{|c|}{ Terhesség alatt kialakuló szemészeti kórképek } \\
\hline \multirow[t]{3}{*}{ Retina } & $\begin{array}{l}\text { Praeeclampsiához társult } \\
\text { retinopathia }\end{array}$ & Látásromlás \\
\hline & $\begin{array}{l}\text { Centrális serosus } \\
\text { chorioretinopathia }\end{array}$ & $\begin{array}{l}\text { Látásromlás, látászava- } \\
\text { rok (centrális scotoma, } \\
\text { micropsia, metamor- } \\
\text { phopsia, színlátászavar) }\end{array}$ \\
\hline & $\begin{array}{l}\text { Vascularis occlusiv } \\
\text { betegségek }\end{array}$ & Látásromlás \\
\hline \multicolumn{3}{|c|}{$\begin{array}{l}\text { Korábbi szembetegségek terhesség hatására bekövetkező progressziója } \\
\text { vagy fellángolása }\end{array}$} \\
\hline \multirow[t]{2}{*}{ Retina } & Diabeteses retinopathia & Látásromlás \\
\hline & Ocularis toxoplasmosis & $\begin{array}{l}\text { Látásromlás } \\
\text { Látótéreltérések }\end{array}$ \\
\hline \multirow[t]{2}{*}{$\begin{array}{l}\text { Chiasma } \\
\text { opticum }\end{array}$} & Hypophysisadenoma & $\begin{array}{l}\text { Látótéreltérések } \\
\text { Diplopia }\end{array}$ \\
\hline & Pseudotumor cerebri & $\begin{array}{l}\text { Átmeneti látásvesztés } \\
\text { Látótéreltérések } \\
\text { Diplopia }\end{array}$ \\
\hline \multicolumn{3}{|c|}{ A szüléshez kapcsolódó szemészeti szövődmények } \\
\hline Conjunctiva & Subconjunctivalis vérzés & \\
\hline Retina & $\begin{array}{l}\text { Valsalva-retinopathia } \\
\text { Purtscher-retinopathia }\end{array}$ & Látásromlás \\
\hline $\begin{array}{l}\text { Chiasma } \\
\text { opticum }\end{array}$ & Sheehan-szindróma & Látótéreltérések \\
\hline
\end{tabular}

sekor és a várandósság során egyaránt. Ismert hypophysisadenoma és idiopathiás intracranialis hypertonia esetén a terhesség alatt látótérvizsgálat elvégzése ajánlott a kompressziós tünetek időben történő felismerése és a maradandó látásromlást megelőző terápia bevezetése céljából. A szülésvezetés módjának szemészeti indikációból történő eldöntéséról az utóbbi évtizedekben paradigmaváltás történt. Habár ezzel kapcsolatban jelenleg nem áll rendelkezésünkre elfogadott irányelv sem a szülészeti, sem a szemészeti szakkollégiumok részéről, irodalmi adatok szerint és a korábbi feltételezésekkel ellentétben a myopiás gravidáknak nincs fokozott kockázatuk a hüvelyi szülés során a retinaleválás kialakulására, a fénytörési hiba mértékétől függetlenül. A rövidlátó várandós nők szemfenéki vizsgálatának függvényében, perifériás retinadegenerációk jelenléte esetén, a szemfenéki lézerkezelés profilaktikus elvégzése a szülés előtt megfontolandó.

Anyagi támogatás: A közlemény megírása, illetve a kapcsolódó kutatómunka anyagi támogatásban nem részesült.

Szerzői munkamegosztás: A vizsgálat tervezése: C. C., K. I., N. Z. Zs. A vizsgálatok elvégzése: C. C., S. G. L., E. M., Sza. D . A közlemény megírása: C. C., K. I. A kézirat kritikai revíziója: S. G. L., E. M., Sza. D., Szé. D., B. J., N. Z. Zs., K. I. A cikk végleges változatát valamennyi szerző elolvasta és jóváhagyta.

Érdekeltségek: A szerzőknek nincsenek érdekeltségeik.

\section{Irodalom}

[1] Mackensen F, Paulus WE, Max R, et al. Ocular changes during pregnancy. Dtsch Arztebl Int. 2014; 111: 567-576.

[2] Sziray A, Károlyi Z. Dermatoses of pregnancy. [Terhességi dermatosisok.] Orv Hetil. 2013; 154: 1407-1416. [Hungarian]

[3] Ogbechie-Godec OA, Elbuluk N. Melasma: an up-to-date comprehensive review. Dermatol Ther (Heidelb). 2017; 7: 305-318.

[4] Suzuki T, Sullivan DA. Estrogen stimulation of proinflammatory cytokine and matrix metalloproteinase gene expression in human corneal epithelial cells. Cornea 2005; 24: 1004-1009.

[5] Rizyal A, Shrestha B, Khadka A. Dry eye disease among pregnant women at a tertiary care hospital in Kathmandu. Nepal Med College J. 2020; 22: 146-152.

[6] Sharma S, Rekha W, Sharma T, et al. Refractive issues in pregnancy. Aust N Z J Obstet Gynaecol. 2006; 46: 186-188.

[7] Pizzarello LD. Refractive changes in pregnancy. Graefes Arch Clin Exp Ophthalmol. 2003; 241: 484-488.

[8] Park SB, Lindahl KJ, Temnycky GO, et al. The effect of pregnancy on corneal curvature. CLAO J. 1992; 18: 256-259.

[9] Suzuki T, Kinoshita Y, Tachibana M, et al. Expression of sex steroid hormone receptors in human cornea. Curr Eye Res. $2001 ; 22: 28-33$.

[10] Ataş M, Duru N, Ulusoy DM, et al. Evaluation of anterior segment parameters during and after pregnancy. Cont Lens Anterior Eye $2014 ; 37$ : 447-450.

[11] Saylik M, Saylik SA. Not only pregnancy but also the number of fetuses in the uterus affects intraocular pressure. Indian J Ophthalmol. 2014; 62: 680-682. 
[12] Razeghinejad MR, Tania Tai TY, Fudemberg SJ, et al. Pregnancy and glaucoma. Surv Ophthalmol. 2011; 56: 324-335.

[13] Alasztics B, Gullai N, Molvarec A, et al. The role of angiogenic factors in preeclampsia. [Az angiogén faktorok szerepe praeeclampsiában.] Orv Hetil. 2014; 155: 1860-1866. [Hungarian]

[14] Nagy ZZs. Review of the ophthalmic symptoms of preeclampsia. Dev Health Sci. 2020; 3: 21-23.

[15] Gupta A, Kaliaperumal S, Setia S, et al. Retinopathy in preeclampsia: association with birth weight and uric acid level. Retina 2008; 28: 1104-1410.

[16] Reddy SC, Nalliah S, George SRA, et al. Fundus changes in pregnancy induced hypertension. Int J Ophthalmol. 2012; 5: 694697.

[17] Nicholson B, Noble J, Forooghian F, et al. Central serous chorioretinopathy: update on pathophysiology and treatment. Surv Ophthalmol. 2013; 58: 103-126.

[18] Kurtz WS, Glueck CJ, Hutchins RK, et al. Retinal artery and vein thrombotic occlusion during pregnancy: markers for familial thrombophilia and adverse pregnancy outcomes. Clin Ophthalmol. 2016; 10: 935-938.

[19] Lertsumitkul S, Whitcup SM, Chan CC. Ocular manifestations of disseminated intravascular coagulation in a patient with the acquired immunodeficiency syndrome. Arch Ophthalmol. 1997; 115: 676-677.

[20] Bobbio-Pallavicini E, Porta C, Brocchieri A, et al. Ocular involvement in acute thrombotic thrombocytopenic purpura. Haematologica 1995; 80: 194-195.

[21] Durrani OM, Gordon C, Murray PI. Primary anti-phospholipid antibody syndrome (APS): current concepts. Surv Ophthalmol 2002; 47: 215-238

[22] Czakó C, Sándor GL, Ecsedy M, et al. Diabeteses kisér-károsodás vizsgálata optikai koherencia tomográfián alapuló angiográfíával. [Evaluation of diabetic microangiopathy using optical coherence tomography angiography.] Orv Hetil. 2018; 159: 320-326. [Hungarian]

[23] Morrison JL, Hodgson LA, Lim LL, et al. Diabetic retinopathy in pregnancy: a review. Clin Exp Ophthalmol. 2016; 44: 321334.

[24] Chew ÚR, Mills JL, Metzger BE, et al. Metabolic control and progression of retinopathy. The diabetes in early pregnancy study. National institute of child health and human development diabetes in early pregnancy study. Diabetes Care 1995; 18: 631637.

[25] Patil AD, Ellabban AA, Patil DB, et al. Ocular manifestations of pregnancy and labour: from the innocuous to the sight threatening. Obstet Gynaecol. 2020; 22: 217-226.

[26] Hirano T, Toriyama Y, Iesato Y, et al. Changes in plasma vascular endothelial growth factor level after intravitreal injection of bevacizumab, aflibercept, or ranibizumab for diabetic macular edema. Retina 2018; 38: 1801-1808.

[27] Rezai S, LoBue S, LoBue TD, et al. Ophthalmic complications and ocular changes in pregnancy. A review. Obstet Gynecol Int J. 2016; 4: 00093

[28] Ennaifer H, Jemel M, Kandar H, et al. Developed diplopia due to a pituitary macroadenoma during pregnancy. Pan Afr Med J. 2018; 29: 39.

[29] Imran SA, Úr E, Clarke DB. Managing prolactin-secreting adenomas during pregnancy. Can Fam Physician 2007; 53: 653658.

[30] Bruce BB, Biousse V, Newman NJ. Update on idiopathic intracranial hypertension. Am J Ophthalmol. 2011; 152: 163-169.

[31] Falardeau J, Lobb BM, Golden S, et al. The use of acetazolamide during pregnancy in intracranial hypertension patients. J Neuroophthalmol. 2013; 33: 9-12.
[32] Andrade GM, Vasconcelos-Santos DV, Carellos EV, et al. Con genital toxoplasmosis from a chronically infected woman with reactivation of retinochoroiditis during pregnancy. J Pediatr (Rio J). 2010; 86: 85-88.

[33] Chiam NP, Lim LL. Uveitis and gender: the course of uveitis in pregnancy. J Ophthalmol. 2014; 2014: 401915

[34] Boerma T, Ronsmans C, Melesse DY, et al. Global epidemiology of use of and disparities in caesarean sections. Lancet 2018; 392: $1341-1348$.

[35] Mohammadi SF, Letafat-Nejad M, Ashrafi E, et al. A survey of ophthalmologists and gynecologists regarding termination of pregnancy and choice of delivery mode in the presence of eye diseases. J Curr Ophthalmol. 2017; 29: 126-132.

[36] Socha MW, Piotrowiak I, Jagielska I, et al. Retrospective analysis of ocular disorders and frequency of cesarean sections for ocular indications in 2000-2008. Our own experience. [Retrospektywna analiza patolog i narz du wzroku i czestości cieć cesarskich ze wskazan okulistycznych w latach 2000-2008 w materiale własnym.] Ginekol Pol. 2010; 81: 188-191. [Polish]

[37] Sapuła-Grabowska M, Ciszewska J, Brydak-Godowska J, et al. Delivery in myopic women: a comparison of mode of delivery in years 1990, 2000, and 2010. Med Sci Monit. 2019; 25: 77157719.

[38] Loncarek K, Petrovic O, Brajac I. Myopia and operative delivery in Croatia. Int J Gynecol Obstet. 2004; 85: 287-288

[39] Chiu H, Steele D, McAlister C, et al. Delivery recommendations for pregnant females with risk factors for rhegmatogenous retinal detachment. Can J Ophthalmol. 2015; 50: 11-18.

[40] Landau D, Seelenfreund MH, Tadmor O, et al. The effect of normal childbirth on eyes with abnormalities predisposing to rhegmatogenous retinal detachment. Graefes Arch Clin Exp Ophthalmol. 1995; 233: 598-600.

[41] Moneta-Wielgos J, Brydak Godowska J, Golebiewska J, et al. The assessment of retina in pregnant women with myopia. Neuro Endocrinol Lett. 2018; 39: 321-324.

[42] Millazo S, Mikou R, Berthout A, et al. Understanding refraction disorders and oculomotor problems during pregnancy. [Comprendre les troubles de la réfraction et les problèmes oculomoteurs pendant la grossesse .] J Fr Ophthalmol. 2010; 33: 368371.

[43] Wielgos M, Bomba-Opoń D, Breborowicz GH, et al. Recommendations of the Polish Society of Gynecologists and Obstetricians regarding caesarean sections. Ginekol Pol. 2018; 89: 644657.

[44] Moneta-Wielgos J, Lipa M, Brydak-Godowska J, et al. Ophthalmological and obstetric management in pregnant women with retinal disorders. Ginekol Pol. 2019; 90: 285-288.

[45] Mimura T, Usui T, Yamagami S, et al. Recent causes of subconjunctival hemorrhage. Ophthalmologica 2010; 224: 133-137.

[46] Ladjimi A, Zaouali S, Messaoud R, et al. Valsalva retinopathy induced by labour. Eur J Ophthalmol. 2002; 12: 336-338.

[47] Deane JS, Ziakas N. Valsalva retinopathy in pregnancy. Eye (Lond). 1997; 11: 137-138.

[48] Blodi BA, Johnson MW, Gass JD, et al. Purtscher's-like retinopathy after childbirth. Ophthalmology 1990; 97: 1654-1659.

[49] Miguel AI, Henriques F, Azevedo LF, et al. Systematic review of Purtscher's and Purtscher-like retinopathies. Eye (Lond). 2013; 27: 1-13.

[50] Shivaprasad C. Sheehan's syndrome: newer advances. Indian J Endocrinol Metab. 2011; 15(Suppl 3): S203-S207.

(Czakó Cecilia dr.,

Budapest, Mária u. 39., 1085 e-mail: cecilia.czako@gmail.com)

A cikk a Creative Commons Attribution 4.0 International License (https://creativecommons.org/licenses/by/4.0/) feltételei szerint publikált Open Access közlemény, melynek szellemében a cikk bármilyen médiumban szabadon felhasználható, megosztható és újraközölhetö, feltéve, hogy az eredeti szerző és a közlés helye, illetve a CC License linkje és az esetlegesen végrehajtott módositások feltüntetésre kerülnek. (SID 1) 